\title{
Propolis Extract as Antioxidant to Improve Oxidative Stability of Fresh Patties during Refrigerated Storage
}

\author{
Rey David Vargas-Sánchez ${ }^{1, \dagger}$, Gastón Ramón Torrescano-Urrutia ${ }^{1}$, \\ Brisa del Mar Torres-Martínez ${ }^{1}$, Mirian Pateiro ${ }^{2, *}$, José Manuel Lorenzo ${ }^{2} \mathbb{D}$ and \\ Armida Sánchez-Escalante ${ }^{1, *}$
}

1 Coordinación de Tecnología de Alimentos de Origen Animal (CTAOA), Centro de Investigación en Alimentación y Desarrollo, A.C. (CIAD), Carretera Gustavo Enrique Astiazarán Rosas, 46, Hermosillo, Sonora 83303, Mexico; rey.vargas@ciad.mx (R.D.V.-S.); gtorrescano@ciad.mx (G.R.T.-U.); brisa.torres@estudiantes.ciad.mx (B.d.M.T.-M.)

2 Centro Tecnológico de la Carne de Galicia, Rúa Galicia No. 4, Parque Tecnológico de Galicia, San Cibrao das Viñas, 32900 Ourense, Spain; jmlorenzo@ceteca.net

* Correspondence: mirianpateiro@ceteca.net (M.P.); armida-sanchez@ciad.mx (A.S.-E.); Tel.: +34-988-548-277 (M.P.); +52-662-289-2400 (A.S.-E.)

+ The author is one of members in this institution of "Consejo Nacional de Ciencia y Tecnología-Centro de Investigación en Alimentación y Desarrollo, A.C.“ (CONACyT-CIAD).

Received: 23 October 2019; Accepted: 21 November 2019; Published: 24 November 2019

\begin{abstract}
The effect of propolis ethanol extract (PEE), butylated hydroxytoluene (BHT), and ascorbic acid (Asc) against lipid (Lox) and protein oxidation (Pox), color deterioration, and the antioxidant stabilizer of raw beef and pork patties during chilled storage ( 9 days at $2{ }^{\circ} \mathrm{C} /$ under darkness) was investigated. Total phenolic content (TPC), reducing power ability (RPA), $\mathrm{DPPH} \bullet$ radical scavenging activity (FRSA) of the PEE was evaluated. Meat samples were evaluated for $\mathrm{pH}$, Lox (TBARS), Pox (Carbonyls), color ( $\mathrm{L}^{*}, \mathrm{a}^{*}, \mathrm{~b}^{*}, \mathrm{C}^{*}$, and $\left.\mathrm{h}^{*}\right)$, metmyoglobin formation (MMb), TPC, RPA, and FRSA. Results indicated that PEE is rich in phenolic content and antioxidant activity, and their incorporation in beef and pork patties reduced $(p<0.05$ ) Lox and Pox (TBARS-88.7 and 80\% inhibition; Pox- 47.3 and $30.6 \%$ inhibition, respectively), as well as loss of color and increased the oxidative stability throughout storage.
\end{abstract}

Keywords: propolis; ethanol extract; antioxidant; meat quality

\section{Introduction}

Meat is an important source of dietary nutrients for human metabolic processes such as lipids, proteins, vitamins, and minerals [1]. Lipids provide indispensable dietary energy and essential nutrients such as essential fatty acids, i.e., mono and polyunsaturated fatty acids (MUFA and PUFA, respectively), while meat protein is distinguished due to its richness in all the essential amino acids [1,2]. However, the secondary metabolites derived from lipid and protein oxidation (Lox and Pox, respectively) are considered causes of quality loss during the processing and storage of meat and meat products and may result in negative effects on sensory and processing properties $[3,4]$. Thus, synthetic antioxidants have been widely used in the meat industry to reduce Lox and Pox process. Nevertheless, the use of synthetic antioxidants, such as propyl gallate (PG), tert-butylhydroquinone (TBHQ), butylated hydroxyanisole (BHA) and butylated hydroxytoluene (BHT), have shown potential health risks [5].

Therefore, there have been efforts to obtain natural antioxidants capable of preserving meat and meat products against undesirable changes caused by oxidation processes [6-8]. Based on their high phenolic composition, natural antioxidant sources, such as fruits (apple, bearberry, blueberry, cranberry, 
pomegranate, strawberry, tomato, among others), vegetables (broccoli, carrot, pumpkin, among others), herbs and spices (black and red pepper, cinnamon, clove, coriander, green tea, moringa, olive, onion, oregano, rosemary, sage, sesame, turmeric, among others) and honeybee products (honey, royal jelly, pollen, and propolis), have shown to decrease oxidation as effectively as synthetic antioxidant [6,9-14].

Propolis is a substance of complex composition and viscous consistency that bees (Apis mellifera) collect from resinous and pollen material from different trees and plants, moistened with saliva and enzymatic secretions, and mixed with the wax produced by the wax glands. In addition, it has been demonstrated that propolis extracts exhibit potential health effects, such as anti-inflammatory, antihypertensive, antidiabetic, antimicrobial, and antioxidant activity, which could be affected by the botanical source, season of collection, and phenolic composition [15,16]. Additionally, it has been proposed as an ingredient to increase the shelf life of fruits, vegetable oils, and meat and dairy products $[17,18]$. Its use as an antioxidant in meat products allowed the reduction of lipid oxidation [19], avoiding the reduction of sensory quality of products associated with changes in color, texture, and appearance of rancid odor and flavor, which influences consumer acceptance [20], as well as a decrease in the nutritional value due to the loss of essential fatty acids and vitamins [4]. In this way, a preliminary study carried out by our research group showed that propolis extract (PE, $2 \%)$ incorporation in bovine and porcine patties significantly reduced $(p<0.05)$ Lox and Pox, as well as color loss, thereby increasing the oxidative stability of patties during refrigerated storage [21].

In addition, novel technologies for the application of propolis extract in meat products, such as its inclusion in packaging materials and the microencapsulation, have been evaluated [22]. In this regard, a recent study evaluated the effect of microencapsulated propolis co-product extract (MPC) on oxidative stability of rear lean beef burgers during frozen storage [23]. The MPC addition inhibited lipid oxidation and did not affect color, appearance, and texture of beef burgers, even improving the results obtained with the synthetic antioxidant. This technique was also applied by other authors in an Italian-type salami, reducing some strong sensorial characteristics associated with the use of propolis [24].

However, data on the effect of propolis addition on beef and pork burgers during cold storage are still limited. Therefore, in this work, the effect of propolis extract on Lox, Pox, color changes, metmyoglobin formation, $\mathrm{pH}$ changes, total phenolic content, free radical scavenging activity, and the reducing power ability of beef and pork patties in comparison to ascorbic acid and butylhydroxytoluene addition was evaluated during cold storage.

\section{Materials and Methods}

\subsection{Chemicals and Reagents}

All the chemical products used were of analytical grade. Folin-Ciocalteu's reagent, sodium carbonate, sodium phosphate, potassium ferricyanide, iron chloride, 1,1-diphenyl-2-picrylhydrazyl $\left(\mathrm{DPPH}^{\bullet}\right)$, ethanol and methanol (HPLC), formic acid, hexane, 2-propanol, butylated hydroxytoluene, ascorbic acid, gallic acid, cinnamic acid, $p$-coumaric acid, ferulic acid, acacetin, apigenin, CAPE (caffeic acid phenetyl esther), chrysin, galangin, luteolin, and quercetin were purchased from Sigma Chemicals (St. Louis, MO, USA). While, 2-thiobarbituric acid and trichloroacetic acid were obtained from J.T. Baker ${ }^{\circledR}$. Naringenin, kaempferol, pinocembrin, pinostrobin, and pinobaksin 3-acetate were purchased from INDOFINE (Chemical Company Inc., Hillsborough, NJ, USA).

\subsection{Propolis Ethanol Extract Preparation (PEE)}

Propolis samples used in this study were collected from the Northwest of Mexico (29.1476 N, $-110.1239 \mathrm{O} ; 632 \mathrm{~m})$. The location presented desert climate characteristics, and the sampling site is surrounded by foothills or thornscrub, dominated by Fabaceae species (Prosopis velutina and Mimosa distachya). Then, phenolic compounds of raw propolis were extracted with ethanol (1:10) at room temperature $\left(25^{\circ} \mathrm{C}\right)$ for 3 days, filtered (Whatman No. 4 filter paper), and concentrated under reduced 
pressure (Rotary evaporator BÜCHI R-200, Flawil, Switzerland), washed with hexane to remove waxes, and stored under dark at $-20^{\circ} \mathrm{C}$, until analysis [25].

\subsection{Phenolic and Antioxidant Activity of PEE}

\subsubsection{Total Phenolic Content}

Total phenolic content (TPC) of PEE was determined according to the Folin-Ciocalteu's procedure [26]. PEE (100 $\mu \mathrm{L}$, at different concentrations) was oxidized with $250 \mu \mathrm{L}$ of Folin-Ciocalteu's reagent $(2 \mathrm{M})$. The mixture was homogenized and incubated for $8 \mathrm{~min}$, under dark conditions. Then, $750 \mu \mathrm{L}$ of $\mathrm{Na}_{2} \mathrm{CO}_{3}(7 \%, \mathrm{w} / \mathrm{v})$ were added. The reaction mixture was incubated for $30 \mathrm{~min}$, under dark conditions. The absorbance was measured at $765 \mathrm{~nm}$ in a spectrophotometer (Model 336001, Spectronic Genesys 5, Thermo Electron Corp., Madison, WI, USA). The results were expressed as mg of gallic acid equivalents/g of extract (mg GAE/g).

\subsubsection{HPLC-DAD Analysis}

The phenolic compounds in PEE were identified using an HPLC system (Varian ProStar, Walnut Creek, CA, USA) equipped with a diode array detector (DAD). The stationary phase was a C18 LiChrospher 5 column $(125 \times 4.0 \mathrm{~mm}, 5 \mathrm{~mm})$. The flow rate was $1 \mathrm{~mL} / \mathrm{min}$ using $5 \%$ formic acid in water and methanol as the elution solvent (solvent $A$ and $B$, respectively). The gradient program profile was as follows: starting with $0 \%$ B ( $0 \mathrm{~min}$ ), 30\% (10-20 $\mathrm{min}$ ), 40\% (20-30 $\mathrm{min}), 45 \%$ (30-50 $\mathrm{min}), 60 \%$ (50-52 $\mathrm{min}$ ), $80 \%$ (52-65 $\mathrm{min}$ ), 100\% (65-70 $\mathrm{min}$ ), and $0 \%(70-71 \mathrm{~min})$. The elution of the compounds was monitored at 280 and $340 \mathrm{~nm}$. The assignation of peaks was performed comparing the retention times using authentic standards solutions and by spiking the samples with the respective compounds. The calibration curves were prepared using each compound (15 to $500 \mu \mathrm{g} / \mathrm{mL}$ ) for quantification, and linear ranges were determined $r \geq 0.99$ [25].

\subsubsection{Reducing-Power Assay}

Reducing-power ability (RPA) was determined by the Prussian blue method [27]. PEE (100 $\mu \mathrm{L}$, at different concentrations) was homogenized with $300 \mu \mathrm{L}$ of phosphate buffer $(0.2 \mathrm{M}, \mathrm{pH} 6.6), 300 \mu \mathrm{L}$ of $1 \%$ potassium ferric cyanide and incubated in a water bath at $50{ }^{\circ} \mathrm{C}$ for $20 \mathrm{~min}$. After, $300 \mu \mathrm{L}$ of $10 \%$ trichloroacetic acid (TCA) were added and centrifuged at $4200 \times g$ for $10 \mathrm{~min}$. The supernatant $(500 \mu \mathrm{L}$ ) was mixed with $100 \mu \mathrm{L}$ of distilled water and $250 \mu \mathrm{L}$ of $0.1 \%$ ferric chloride. The absorbance was measured at $700 \mathrm{~nm}$. The results were expressed as absorbance increase at the same wavelength.

\subsubsection{Free-Radical Scavenging Activity}

The DPPH $\bullet$ radical-scavenging activity (FRSA) was determined [28]. The PEE (500 $\mu \mathrm{L})$ were homogenized with $500 \mu \mathrm{L}$ of DPPH ${ }^{\bullet}$ ethanol solution $(300 \mu \mathrm{M})$ and incubated at room temperature for $30 \mathrm{~min}$. The absorbance was measured at $517 \mathrm{~nm}$. FRSA was calculated as (Ac-As) $\times 100 / A c$, where Ac is the absorbance of the control ( $t=0 \mathrm{~min})$, and As is the absorbance of the sample ( $t=30 \mathrm{~min})$.

\subsection{Beef and Pork Patties Manufacture}

The patties were prepared, as described previously [29]. Fresh beef and pork minced meat were obtained from Semimembranosus muscle after $48 \mathrm{~h}$ postmortem at a local processor and mixed in separate batches with $1.5 \%$ salt $(\mathrm{NaCl}, \mathrm{w} / \mathrm{w})$, and $10 \%$ of beef and pork back fat, respectively, in the final formulation $(\mathrm{w} / \mathrm{w})$. A total of 24 patties $(25 \mathrm{~g} /$ patty) per treatment were formed and placed on a Styrofoam ${ }^{\mathrm{TM}}$ tray. The polystyrene trays with patties were wrapped with polyvinyl chloride film $\left(17,400 \mathrm{~cm}^{3} \mathrm{O}_{2} / \mathrm{m}^{2} / 24 \mathrm{~h}\right.$ at $\left.23{ }^{\circ} \mathrm{C}\right)$. The patties were subjected to refrigerated storage at $2{ }^{\circ} \mathrm{C}$ under dark for $0,3,6$, and 9 days, and 2 packs were opened for subsequent analysis for each formulation. In each replication (twice), beef and pork patties were assessed in eight treatments as follows: (1) B (negative control, beef patties without antioxidant); (2) B+PEE (beef patties with $2 \%$ of PEE, w/w); 
(3) B+BHT (positive control, beef patties with $0.02 \%$ of BHT, fat basis w/w); (4) B+Asc (positive control, beef patties with $0.015 \%$ of Asc, w/w); (5) $\mathrm{P}$ (negative control, porcine patties without antioxidant); (6) $\mathrm{P}+\mathrm{PEE}$ (porcine patties with $2 \%$ of $\mathrm{PEE}, \mathrm{w} / \mathrm{w}$ ); (7) $\mathrm{P}+\mathrm{BHT}$ (positive control, porcine patties with $0.02 \%$ of BHT, w/w); (8) P+Asc (positive control, porcine patties with $0.015 \%$ of Asc, w/w).

\subsection{Phenolic and Antioxidant Activity of Meat Extract}

Phenolic and antioxidant activity of meat extract was assayed by TPC, RPA, and FRSA methods. The meat extract was obtained homogenizing beef and pork patties with ethanol $(1: 10, \mathrm{w} / \mathrm{v})$ at $4200 \times g$ for $10 \mathrm{~min}$ at $4{ }^{\circ} \mathrm{C}$. Then, the resulting supernatant was employed to carry out the aforementioned measurements [30].

\section{6. $\mathrm{pH}$ and Color Changes of Patties}

\subsection{1. $\mathrm{pH}$ Measurement}

Meat samples were homogenized with distilled water (1:10, w/v) at $4500 \mathrm{rpm}$ for $1 \mathrm{~min}$ (Ultra-Turrax model T25, IKA ${ }^{\circledR}$, Staufen, Germany) in an ice bath. $\mathrm{pH}$ values were measured with a potentiometer equipped with a glass electrode and automatic compensation of temperature (Model pH211, Hanna Instruments Inc., Woonsocket, RI, USA.) [31].

\subsubsection{Color Measurement}

The color changes were measured using a spectrophotometer (model CM 508d, Konica Minolta Inc., Tokyo, Japan). The values registered were lightness $(\mathrm{L} *)$, redness $(\mathrm{a} *)$, yellowness $(\mathrm{b} *)$, chromaticity $(C *)$, and hue angle $(h *)$. The beef and pork patties were extracted from their packaging and exposed at $4{ }^{\circ} \mathrm{C}$ for $30 \mathrm{~min}$. In total, 10 measurements were performed on the surface of each sample [32].

\subsubsection{Metmyoglobin Formation}

The metmyoglobin formation ( $\mathrm{MMb}$ ) was determined spectrophotometrically [33]. The maximum value of the quotient K/S525 and K/S572 at the beginning of the experiment (day 0) was fixed as 0\% $\mathrm{MMb}$, while $100 \% \mathrm{MMb}$ was obtained after oxidizing a beef and pork patties in potassium ferricyanide $(1 \%, w / v)$. In total, 10 measurements were performed on the surface of each sample, and results were expressed as a percentage of $\mathrm{MMb}$.

\subsection{Oxidative Stability of Patties}

\subsubsection{Lipid Oxidation}

Lipid oxidation (Lox) was measured by the thiobarbituric acid reactive substances (TBARS) method [34]. Meat samples (10 g) were homogenized with $20 \mathrm{~mL}$ of $10 \%$ trichloroacetic acid at $4500 \mathrm{rpm}$ for $1 \mathrm{~min}$, in an ice bath. After, the slurry was centrifuged (at $2300 \times \mathrm{g} / 4^{\circ} \mathrm{C} /$ for $20 \mathrm{~min}$ ) and filtered (Whatman 4 filter paper). In total, $2 \mathrm{~mL}$ of filtrate were mixed with $2 \mathrm{~mL}$ of TBA $(0.02 \mathrm{M})$ in test tubes, placed in a water bath $\left(97-98^{\circ} \mathrm{C}\right)$ for $20 \mathrm{~min}$, and subsequently cooled. The absorbance was measured at $531 \mathrm{~nm}$. TBARS values were calculated from a 1,1,3,3-tetramethoxypropane standard curve and expressed as mg malondialdehyde/ $\mathrm{kg}$ of the meat sample (mg MDA/kg).

\subsubsection{Protein Oxidation}

Protein oxidation (Pox) was measured by the total carbonyl content was evaluated by derivatization with dinitrophenylhydrazine (DNPH) [35]. Meat samples $(1 \mathrm{~g})$ were homogenized $(1: 10, \mathrm{w} / \mathrm{v})$ in $20 \mathrm{mM}$ sodium phosphate buffer containing $0.6 \mathrm{M} \mathrm{NaCl}$ (pH 6.5) at $4500 \mathrm{rpm}$ for $1 \mathrm{~min}$. Two equal aliquots of $0.2 \mathrm{~mL}$ were taken from homogenates and each dispensed in $2 \mathrm{~mL}$ test tubes. Proteins were precipitated with $1 \mathrm{~mL}$ of cold TCA $(10 \%, \mathrm{w} / \mathrm{v})$ and subsequently centrifuged at $4200 \times \mathrm{g} / 4^{\circ} \mathrm{C} /$ for $5 \mathrm{~min}$ (one pellet was treated with $1 \mathrm{~mL}$ of $2 \mathrm{M} \mathrm{HCl}$ for protein concentration measurement and the other 
with an equal volume of DNPH in $2 \mathrm{M} \mathrm{HCl}$ for carbonyl concentration measurement). Both samples were incubated at room temperature for $1 \mathrm{~h}$. After, samples were precipitated with $1 \mathrm{~mL}$ of TCA $(10 \%$, $\mathrm{w} / \mathrm{v})$ and washed twice with $1 \mathrm{~mL}$ of ethanol:ethyl acetate $(1: 1, \mathrm{v} / \mathrm{v})$ to remove excess DNPH. Then, each pellet was mixed with $1.5 \mathrm{~mL}$ of $20 \mathrm{mM}$ sodium phosphate buffer containing $6 \mathrm{M}$ guanidine $\mathrm{HCl}$ (pH 6.5), stirred and centrifuged at $4200 \times \mathrm{g} / 4^{\circ} \mathrm{C} /$ for $2 \mathrm{~min}$ to remove insoluble fragments. Protein concentration was calculated from absorption at $280 \mathrm{~nm}$ using BSA as the standard. The amount of carbonyls was expressed as $\mathrm{nM}$ of carbonyl per $\mathrm{mg}$ of protein using a molar absorption coefficient of $21 \mathrm{nM}^{-1} \times \mathrm{cm}^{-1}$ at $370 \mathrm{~nm}$ for protein hydrazones.

\subsection{Statistical Analysis}

Three independent experimental trials (replications) were conducted, and the results were presented as the mean \pm standard deviation. Data of experimental patties were submitted to analysis of variance (ANOVA) according to a two factorial design using NCSS statistical software (2007). Normal distribution and variance homogeneity were previously tested (Shapiro-Wilk). The treatments (B, B+PEE, B+BHT, B+Asc, $\mathrm{P}, \mathrm{P}+\mathrm{PEE}, \mathrm{P}+\mathrm{BHT}$, and $\mathrm{P}+\mathrm{Asc})$ and storage times $(0,3,7$, and 10 days) were the fixed terms in the model. A Tukey-Kramer multiple comparison test was performed to determine the significance of mean values for multiple comparisons at $\alpha<0.05$.

\section{Results}

\subsection{Polyphenol Composition and Antioxidant Activity}

As shown in Table 1, PEE was tested for total phenolic content (TPC) and antioxidant activity (i.e., reducing-power ability, RPA; and, free-radical scavenging activity, FRSA). The results showed that PEE had high TPC ( $>400 \mathrm{mg} \mathrm{GAE} / \mathrm{g}$ ), RPA ( $>50 \%$ of reduction), and FRSA ( $>50 \%$ of radical inhibition) in concentration-dependence $(p<0.05)$. While the standards (BHT $>$ Asc) showed the highest antioxidant activity $(>50 \%)$.

Table 1. Total phenolic content and antioxidant activity of propolis ethanol extract (PEE).

\begin{tabular}{cccc}
\hline$(\mu \mathrm{g} / \mathrm{mL})$ & TPC $(\mathbf{m g ~ G A E} / \mathbf{g})$ & RPA (Abs) & FRSA (\%) \\
\hline 500 & $472.3 \pm 3.50^{\mathrm{f}}$ & $0.56 \pm 0.03^{\mathrm{g}}$ & $69.1 \pm 0.03^{\mathrm{e}}$ \\
250 & $288.1 \pm 0.53^{\mathrm{e}}$ & $0.34 \pm 0.01^{\mathrm{e}}$ & $45.7 \pm 0.11^{\mathrm{d}}$ \\
100 & $198.5 \pm 0.98^{\mathrm{d}}$ & $0.20 \pm 0.01^{\mathrm{d}}$ & $33.0 \pm 0.01^{\mathrm{c}}$ \\
50 & $152.5 \pm 1.22^{\mathrm{c}}$ & $0.14 \pm 0.01^{\mathrm{c}}$ & $31.0 \pm 0.05^{\mathrm{b}}$ \\
25 & $126.6 \pm 0.24^{\mathrm{b}}$ & $0.10 \pm 0.01^{\mathrm{b}}$ & $30.0 \pm 0.01^{\mathrm{b}}$ \\
12.5 & $122.9 \pm 0.53^{\mathrm{a}}$ & $0.07 \pm 0.01^{\mathrm{a}}$ & $28.7 \pm 0.01^{\mathrm{a}}$ \\
BHT $(50 \mu \mathrm{g} / \mathrm{mL})$ & ND & $0.7 \pm 0.01^{\mathrm{h}}$ & $70.8 \pm 0.10^{\mathrm{e}}$ \\
Asc $(25 \mu \mathrm{g} / \mathrm{mL})$ & ND & $1.0 \pm 0.01^{\mathrm{i}}$ & $73.0 \pm 0.10^{\mathrm{f}}$
\end{tabular}

ND: not determined. Data represent mean \pm standard deviation. Different superscripts (a-i) within the same column differ significantly $(p<0.05)$.

In addition, as shown in Table 2, the phenolic compounds identified in PEE were gallic acid, cinnamic acid, p-coumaric acid, naringenin, quercetin, luteolin, kaempferol, apigenin, pinocembrin, pinobanksin 3-acetate, caffeic acid phenethyl ester (CAPE), chrysin, galangin, acacetin, and pinostrobin. However, pinocembrin, naringenin, and galangin were the most abundant flavonoids in the extract $(p<0.05)$. 
Table 2. Phenolic compounds identified in PEE by ethanol and methanol diode array detector (HPLC-DAD).

\begin{tabular}{cccc}
\hline$\#$ & Compound & Retention Time (min) & PEE $\left(\mathbf{m g} / \mathbf{g}^{\mathbf{a}}\right.$ \\
\hline 1 & Gallic acid & 1.9 & $(+)$ \\
2 & Cinnamic acid & 3.4 & $2.1 \pm 0.2^{\mathrm{b}}$ \\
3 & -coumaric acid $^{\mathrm{c}}$ & 7.8 & $2.9 \pm 0.1^{\mathrm{c}}$ \\
4 & Ferulic acid & 8.7 & $(-)$ \\
5 & Naringenin & 27.3 & $50.2 \pm 5.9^{\mathrm{j}}$ \\
6 & Quercetin & 30.8 & $6.5 \pm 0.2^{\mathrm{f}}$ \\
7 & Luteolin & 36.4 & $3.7 \pm 0.2^{\mathrm{d}}$ \\
8 & Kaempferol & 37.2 & $0.9 \pm 0.2^{\mathrm{a}}$ \\
9 & Apigenin & 40.6 & $4.4 \pm 0.2^{\mathrm{e}}$ \\
10 & Pinocembrin & 44.5 & $130.7 \pm 1.8^{\mathrm{k}}$ \\
11 & Pinobanksin 3-acetate & 45.8 & $(+)$ \\
12 & CAPE & 49.0 & $(+)$ \\
13 & Chrysin & 51.4 & $12.3 \pm 1.0^{\mathrm{h}}$ \\
14 & Galangin & 52.4 & $37.0 \pm 2.1^{\mathrm{i}}$ \\
15 & Acacetin & 57.0 & $8.4 \pm 0.4^{\mathrm{g}}$ \\
16 & Pinostrobin & 62.9 & $(+)$ \\
\hline
\end{tabular}

$(+)$, compound identified but not quantified; $(-)$, compound not identified. Data represent mean \pm standard deviation. Different superscripts $(a-k)$ within the same column differ significantly $(p<0.05)$.

\subsection{Total Antioxidant Activity of Meat Extract}

As shown in Figure 1, meat extract from beef and pork patties treated with PEE and synthetic antioxidants were obtained each sampling day and tested for the total antioxidant activity, which was measured through the TPC, RPA, and FRSA. The results showed that treatment $\times$ storage time had a significant effect on these parameters $(p<0.001)$. At day 0 of storage, the highest TPC $(>160 \mathrm{mg}$ GAE/g for both meat types), RPA (0.56 and 0.47 abs, respectively), and FRSA ( $98.8 \%$ and $93 \%$ of radical inhibition, respectively) were found in beef and pork patties treated with PEE, in comparison to synthetic antioxidants and control samples. However, these values significantly decreased during storage time for all treatments $(p<0.05)$. At the end of storage (day 9$)$, beef $(55.8 \%, 54.6 \%$, and $38.2 \%$, respectively) and pork (46.9\%, $43.7 \%$, and $28.8 \%$, respectively) patties treated with antioxidants showed higher values $(p<0.05)$ of TPC than the control samples. In this way, the best results were found in the samples treated with PEE, followed by BHT and Asc. Also, beef and pork patties treated with PEE and BHT showed the highest values of RPA (46.3\% and 34.8\%, respectively), in comparison to the control and Asc treatments $(p<0.05)$. In addition, beef patties treated with PEE had higher FRSA values $(p<0.05)$ than those treated with synthetic antioxidants $(97.8 \%, 96.3 \%$, and $90.3 \%$ for PEE, BHT, and Asc, respectively); while, pork samples treated with PEE showed the highest FRSA (97.9\%) in comparison to BHT, which displayed similar values to Asc and the control samples $(p<0.05)$. 
A)

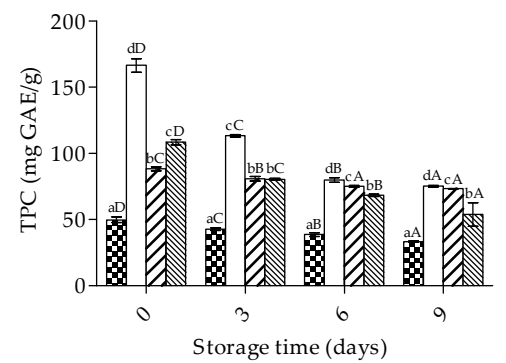

B)

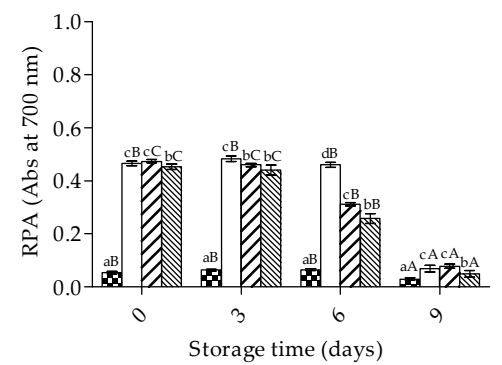

C)

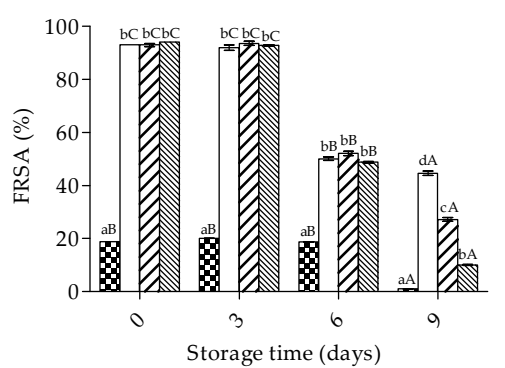

8 в

$\square$ B+PEE

ZA B+BHT

$\mathbb{B}$ B + Asc

$\otimes$ B

$\square$ B + PEE

Z B B BHT

$\mathbb{B}+$ Asc

8 в

$\square$ B+PEE

$\mathrm{B}+\mathrm{Asc}$
Pork patties

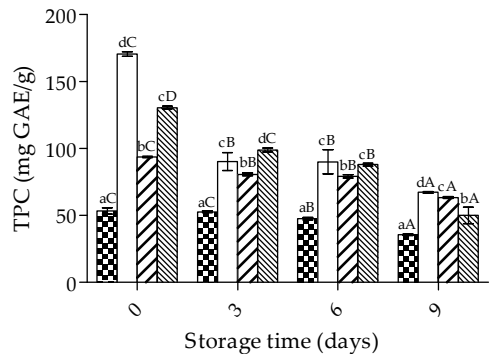

Q $\mathrm{P}$

$\square$ P+PEE

ZI P+BHT

P+Asc

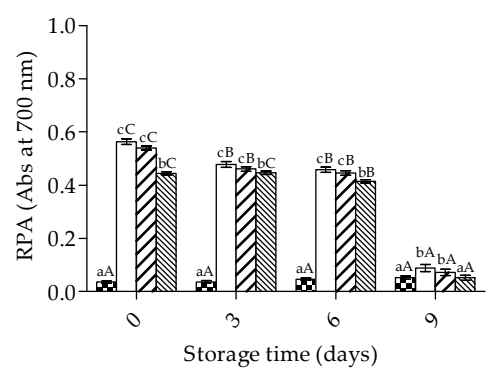

$8 \mathrm{P}$

$\square$ P+PEE

Z $\mathrm{P}+\mathrm{BHT}$

$\mathbb{P}+\mathrm{Asc}$

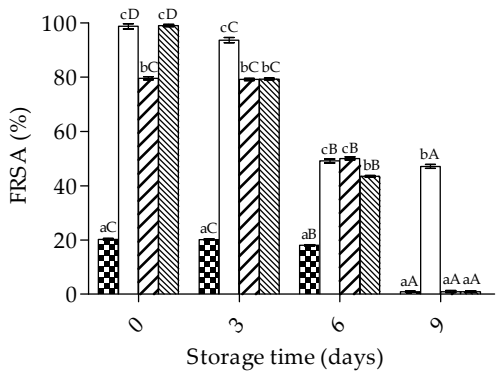

O $\mathrm{P}$

$\square$ P+PEE

VIA P+BHT

P+Asc

Figure 1. Antioxidant values of beef and pork patties during storage time determined by the total phenolic content (A), reducing power ability (RPA) (B), and $\mathrm{DPPH}^{\bullet}$ radical scavenging activity (FRSA) (C). B, beef patties without antioxidant; B+PEE, beef patties with the extract; B+BHT, beef patties with $0.02 \%$ of BHT; B+Asc, beef patties with ascorbic acid $0.015 \%$. P, pork patties without antioxidant; $\mathrm{P}+\mathrm{PEE}$, pork patties with the extract; $\mathrm{P}+\mathrm{BHT}$, pork patties with $0.02 \%$ of $\mathrm{BHT}$; $\mathrm{P}+\mathrm{Asc}$, pork patties with ascorbic acid $0.015 \%$. Different superscripts within the same sampling day $(\mathrm{a}-\mathrm{d})$ and though storage (A-D) differ significantly $(p<0.05)$.

\section{3. $p H$ and Oxidation Values of Patties}

As shown in Figure 2, beef and pork patties were tested for the $\mathrm{pH}$, Lox, and Pox. The results showed that treatment $\times$ storage time had a significant effect on these parameters $(p<0.001)$. At day 0 of storage, the lowest TBARS and carbonyl formation values were found in samples treated with any antioxidant $(p<0.05)$, while no significant differences were shown in $\mathrm{pH}$ values $(p>0.05)$. However, these values significantly decreased during storage time $(p<0.05)$. At the end of storage, beef and pork patties treated with PEE showed the highest $\mathrm{pH}$ values (5.5 and 5.6, respectively), as well as the lowest meat oxidation values $(<0.5 \mathrm{mg} \mathrm{MDA} / \mathrm{kg}$; and $<1.5 \mathrm{nM}$ carbonyl $/ \mathrm{mg}$ for both meat types $)(p<0.05)$. 
A)

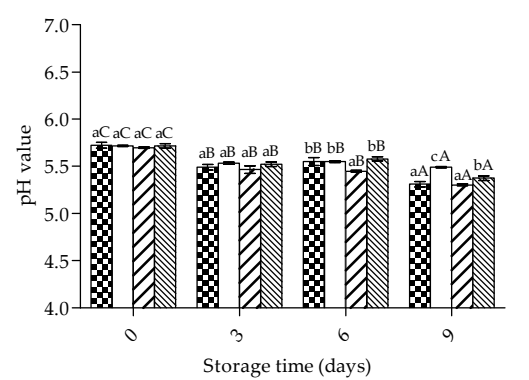

B)

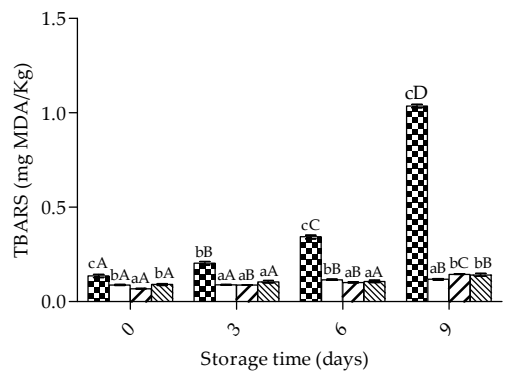

C)

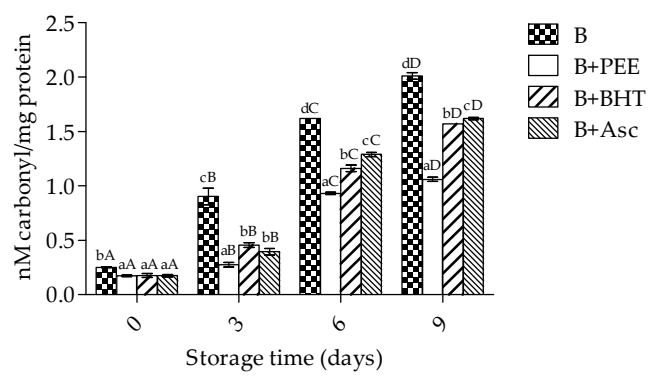

Pork patties
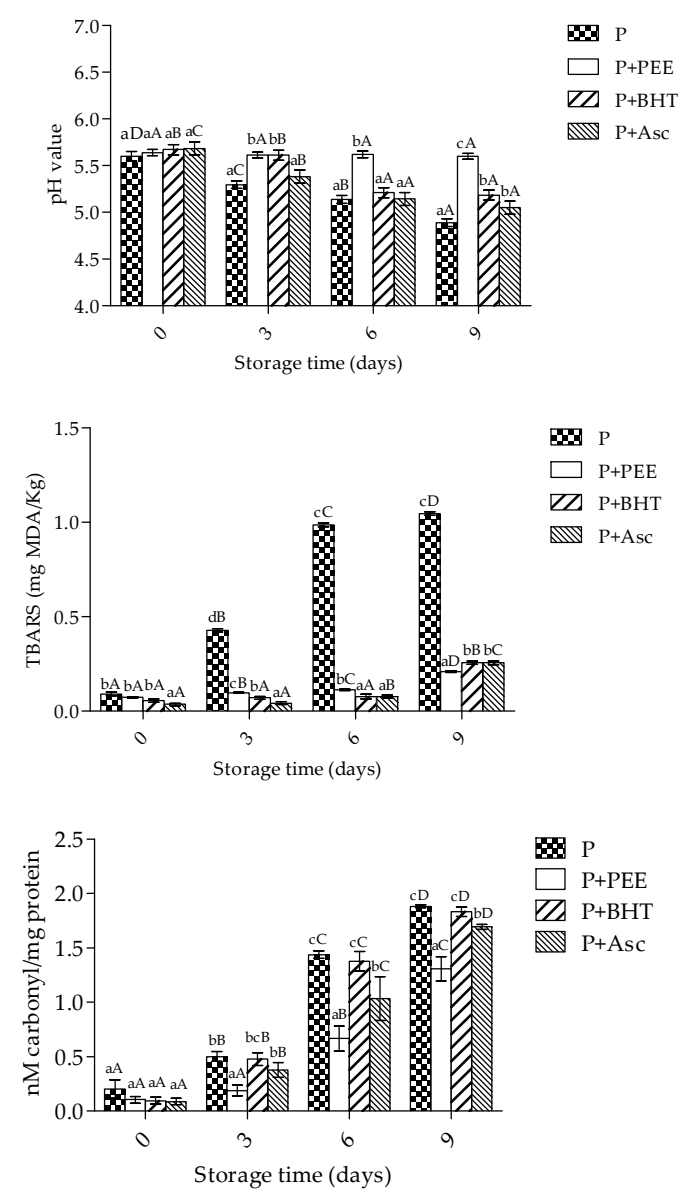

Figure 2. $\mathrm{pH}$ (A), Lox (RPA) (B), and Pox values (C) of beef and pork patties during storage time. $\mathrm{B}$, beef patties without antioxidant; $\mathrm{B}+\mathrm{PEE}$, beef patties with the extract; $\mathrm{B}+\mathrm{BHT}$, beef patties with $0.02 \%$ of BHT; $\mathrm{B}+$ Asc, beef patties with ascorbic acid $0.015 \%$. P, pork patties without antioxidant; $\mathrm{P}+\mathrm{PEE}$, pork patties with the extract; $\mathrm{P}+\mathrm{BHT}$, pork patties with $0.02 \%$ of $\mathrm{BHT}$; $\mathrm{P}+\mathrm{Asc}$, pork patties with ascorbic acid $0.015 \%$. Different superscripts within the same sampling day $(a-d)$ and though storage $(A-D)$ differ significantly $(p<0.05)$.

\subsection{Metamyoglobin Formation of Patties}

As shown in Figure 3, beef and pork patties were tested for MMb formation, and results showed that treatment $\times$ storage time had a significant $(p<0.001)$ effect on this parameter. At day 0 of storage, the results showed no significant differences in MMb formation in all pork patties $(p>0.05)$, while the highest $\mathrm{MMb}$ formation $(>10 \%)$ was found in beef patties from the control group $(p<0.05)$. In addition, these values significantly increased during storage time $(p<0.05)$. At the end of storage, beef and pork patties treated with PEE showed the lowest MMb content $(<40 \%$ of MMb for both meat types) $(p<0.05)$. 


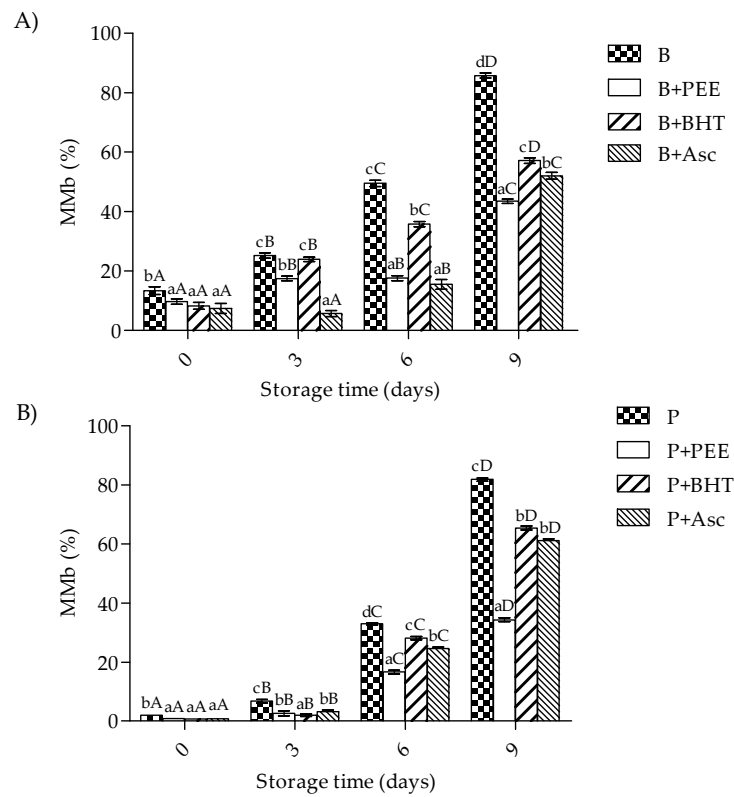

Figure 3. Metmyoglobin formation (MMb) formation in beef $(\mathbf{A})$ and pork patties $(\mathbf{B})$ during storage time. B, beef patties without antioxidant; $\mathrm{B}+\mathrm{PEE}$, beef patties with the extract; $\mathrm{B}+\mathrm{BHT}$, beef patties with $0.02 \%$ of BHT; B+Asc, beef patties with ascorbic acid $0.015 \%$. P, pork patties without antioxidant; $\mathrm{P}+\mathrm{PEE}$, pork patties with the extract; $\mathrm{P}+\mathrm{BHT}$, pork patties with $0.02 \%$ of $\mathrm{BHT}$; $\mathrm{P}+\mathrm{Asc}$, pork patties with ascorbic acid $0.015 \%$. Different superscripts within the same sampling day $(\mathrm{a}-\mathrm{d})$ and though storage (A-D) differ significantly $(p<0.05)$.

\subsection{Color Changes of Patties}

As shown in Table 3, beef and pork patties were tested for color change analysis, and the results showed that the treatment $\times$ storage time effect was significant $(p<0.001)$. At day 0 of storage, the results of $L^{*}$ values showed no significant effect by antioxidant addition in beef and pork patties $\left(\mathrm{L}^{*}=44.8\right.$ and 55.6, respectively). These values significantly increased during storage time $(p<0.05)$. At the end of storage, beef and pork patties treated with PEE and BHT showed the lowest $\mathrm{L}^{*}$ values $\left(L^{*}=45.7\right.$ and 57.4 , respectively) $(p<0.05)$. In addition, initial $\mathrm{a}^{*}$ values showed no significant differences between treatments in beef and pork patties ( $\mathrm{a}^{*}=22.8$ and 20.4, respectively). These values significantly decreased during storage time $(p<0.05)$. At the end of storage, beef and pork patties treated with PEE showed the highest $\mathrm{a}^{*}$ values $\left(\mathrm{a}^{*}=15.0\right.$ and 15.7 , respectively) $(p<0.05)$. While at day 0 of storage, the results showed that patties treated with PEE showed the highest $b^{*}$ values $\left(b^{*}=20.4\right.$ and 21.8, respectively) $(p<0.05)$. These values decreased during storage time $(p<0.05)$. At the end of storage, beef and pork patties treated with PEE showed the highest $b^{*}$ values $\left(b^{*}=17.5\right.$ and 19.1, respectively) $(p<0.05)$. Moreover, at day 0 of storage, the $\mathrm{C}^{*}$ and $\mathrm{h}^{*}$ values were reduced and increased by PEE addition for both meat type, respectively. At the end of storage, beef and pork patties treated with PEE showed the highest $C^{*}$ values $\left(C^{*}=23.7\right.$ and 24.4 , respectively), as well as the lowest $h^{*}$ values ( $h^{*}=46.5$ and 46.1, respectively) $(p<0.05)$. 
Table 3. Instrumental color measured during storage time on the surface of beef and pork patties.

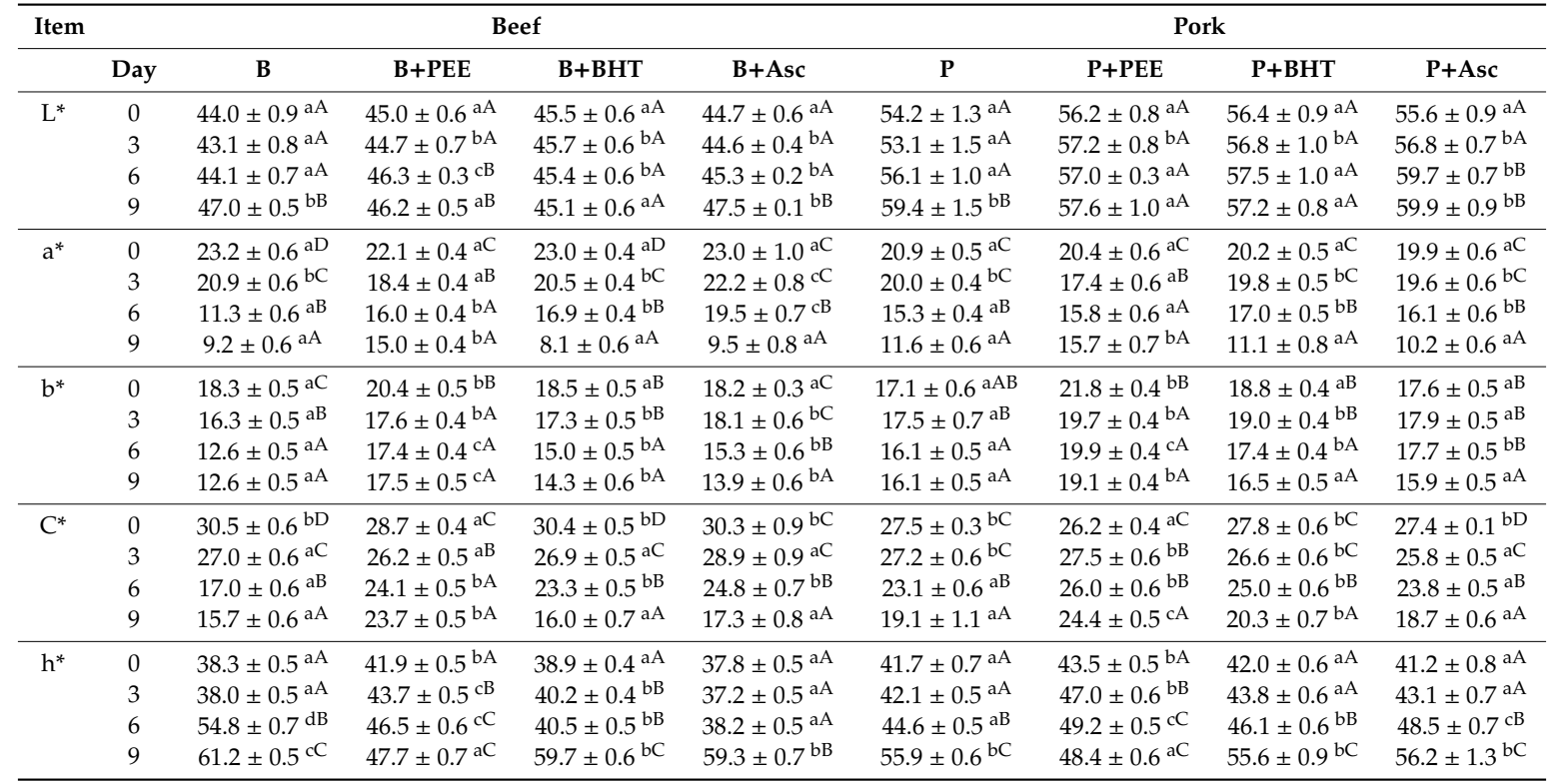

Data represent mean \pm standard deviation. $\mathrm{B}$, beef patties without antioxidant; $\mathrm{B}+\mathrm{PEE}$, beef patties with the extract; B+BHT, beef patties with $0.02 \%$ of BHT; B+Asc, beef patties with ascorbic acid $0.015 \%$. P, pork patties without antioxidant; $\mathrm{P}+\mathrm{PEE}$, pork patties with the extract; $\mathrm{P}+\mathrm{BHT}$, pork patties with $0.02 \%$ of $\mathrm{BHT}$; $\mathrm{P}+\mathrm{Asc}$, pork patties with ascorbic acid $0.015 \%$. Different superscripts within the same sampling day (a-d) and though storage (A-D) differ significantly $(p<0.05)$.

\section{Discussion}

Phenolic compounds, one of the major groups found in plants and honeybee products, have been reported to possess antioxidant activity [36]. The Folin-Ciocalteau method is considered the main tool for measuring the TPC and estimating the amount of antioxidant compounds in extracts from different natural sources [26]. The results obtained showed that PEE is an important source of phenolic constituents, such as phenolic acids and their esters and flavonoids. These findings are in agreement with those previously observed by other authors [36]. Whence, PEE was analyzed by HPLC-DAD in order to identify the phenolic composition, and the results showed that flavanones pinocembrin and naringenin, and the flavonol galangin, represent the major $(80.1 \%)$ compounds quantified. In agreement with our work, it has been reported that pinocembrin and galangin flavonoids are the main phenolic compound in propolis extracts from semiarid regions $[25,37]$.

Phenolic compounds can act in many different ways: 1) reducing metals such as iron $\left(\mathrm{Fe}^{3+}\right)$ and copper $\left(\mathrm{Cu}^{2+}\right)$; and 2) breaking chain reactions triggered by free-radicals, which implies the hydrogen atom transfer (HAT), sequential proton-loss electron-transfer (SPLET) and electron transfer followed by proton transfer mechanism (SET-PT) [38,39]. However, the solvent properties, radical characteristics, and number and position of the hydroxyl group $(\mathrm{OH})$ and first reaction $\mathrm{OH}$-site in the phenolic compound determine these antiradical mechanisms [39]. There are available methods used to assay the RPA and FRSA of natural extracts [27,28]. In our study, PEE showed high RPA and FRSA values (0.56 abs and $69 \%$, respectively) in concentration-dependence, which was significantly correlated with the TPC $\left(r^{2}=0.997\right)$. In agreement with our study, it has been reported that PEE collected in Turkey exerted high RPA and FRSA (i.e., $>50 \%$ of activity) in concentration-dependence [40].

The presence of phenolic compounds in natural extracts is highly correlated with the antioxidant activity, whence the natural extracts incorporation to meat and meat products could be an important strategy to improve oxidative stability during storage [6,41]. It has been reported that meat antioxidant stability could be affected by endogenous and non-enzymatic antioxidants, animal species, animal diet, muscle type, lipid composition, and by the ingredients used in the formulation of meat products (e.g., synthetic antioxidant, chloride salt content, and phenolic content of some species or extract) $[42,43]$. 
In this context, the presence of phenolic compounds and antioxidant activity of meat extracts have been measured in raw and meat products through the TPC, RPA, and FRSA methods [43]. In our study, samples treated with PEE showed higher TPC, RPA, and FRSA values than those obtained for control during all storage time. In agreement, this has been demonstrated the presence of TPC in raw reindeer (Longissimus dorsi and Semimembranosus, 27 and $29 \mathrm{mg} \mathrm{GAE} / \mathrm{g}$, respectively), and raw beef meat (L. dorsi, $17.8 \mathrm{mg} \mathrm{GAE} / \mathrm{g}$ ) untreated with antioxidants [44]. Also, it has been reported that the incorporation of sage essential oil $(3 \%, \mathrm{w} / \mathrm{w})$ on raw and cooked beef and pork meat increased the FRSA ( $>50 \%$ of inhibition by both) during storage (12 days at $4{ }^{\circ} \mathrm{C}$ ) in comparison to the control [45]. In another work, the incorporation of Lotus rhizome knot and leaf extracts on raw and cooked beef and pork ground meat increased the RPA and FRSA ( $>50 \%$ of activity by both) during storage (10 days at $4{ }^{\circ} \mathrm{C}$ ), compared to the values obtained for the control [15]. In agreement, it has been reported that the addition of destoned olive cake powder in raw beef patties increased FRSA (17.8\%) during 14 days of storage at $4{ }^{\circ} \mathrm{C}$ in comparison to the control [46].

In our study, the results of $\mathrm{pH}$, Lox, and Pox values showed a significant treatment $\times$ storage time effect on these parameters $(p<0.001)$. The initial average $\mathrm{pH}$ values in beef and pork patties $(5.7$ and 5.5 , respectively) remained in the characteristic value for fresh meat $[30,47]$. However, $\mathrm{pH}$ values decreased during storage in beef and porcine samples without antioxidants. In disagreement with our work, no significant differences were found in beef patties treated with PEE $(2 \%, w / w)$ during storage ( 8 days at $4{ }^{\circ} \mathrm{C}$ ) [29]. However, it has been demonstrated that a decrease in the $\mathrm{pH}$ value of meat has a great impact on sensory attributes (texture-tenderness, appearance-color, flavor) and the oxidative stability of meat, Lox, and Pox [47,48].

It has been reported that Lox occurs via a free-radical chain reaction that proceeds through three steps (initiation, propagation, and termination) [4]. Lipid hydroperoxides ( $\mathrm{ROOH}$ ) have been identified as primary products of autoxidation, while $\mathrm{ROOH}$ decomposition, alcohols, ketones, hydrocarbons, volatile organic acids, aldehydes, among others, known as secondary oxidation products $[34,49]$. Aldehydic products such as malondialdehyde (MDA), can be measured by the reaction with thiobarbituric acid (TBARS). Thus, it is used commonly as a Lox index for meat products $[50,51]$. In our study, TBARS values were increased during storage time regardless low temperatures $\left(2{ }^{\circ} \mathrm{C}\right)$; however, at the end of storage, the incorporation of antioxidants decreased Lox in the order PEE $>$ BHT $=$ Asc in beef $(88.7 \%$ and $86.2 \%$, respectively) and pork patties $(80 \%$ and $75.5 \%$, respectively) in comparison to control. Also, results have shown that treatments with antioxidants not exceeding the limit value (higher than $0.6 \mathrm{mg} \mathrm{MDA} / \mathrm{kg}$ ) were used for a rancid flavor in a meat product [52]. In addition, it has been reported the potential of another natural source of antioxidants against Lox, like clove extract, which decreased the Lox (>90\%) of fresh beef patties during 10 days of storage in comparison to synthetic antioxidant (BHT and Asc) and control samples [53].

In agreement with our study, cured pork sausages were treated with some antioxidants (PEE: ethanol-extracted propolis, $0.4 \% \mathrm{w} / \mathrm{w}$; WEP: water-extracted propolis, $0.6 \% \mathrm{w} / \mathrm{w}$; DREEP: dried residue of ethanol-extracted propolis, $0.8 \% \mathrm{w} / \mathrm{w}$; PS: potassium sorbate, $0.1 \% \mathrm{w} / \mathrm{w}$ ) and stored during four weeks at 5,10 , and $20^{\circ} \mathrm{C}$. At the end of storage, the results showed that PEE, WEEP, DREEP, and PS decreased Lox $(50 \%, 59 \%, 35 \%$, and $91 \%$, respectively) in comparison to the control [54]. While, in another work, PEE reduced Lox $(78.5 \%)$ in beef patties during storage $\left(8\right.$ days at $\left.2{ }^{\circ} \mathrm{C}\right)$, which was associated with the presence of phenolic compounds such as quercetin, pinocembrin, kaempferol, and luteolin [29].

In addition, it has been reported that the hydrophobic and hydrophilic groups of phenolic compounds allowed the molecule to interact with non-lipidic and lipidic components. While, 3-hydroxylation of the C-ring, non-modification of the B-ring, and 5,7-hydroxylation of the A-ring allowed the highest membrane interactivity, follow by $3^{\prime}, 4^{\prime}$-dihydroxylation of the B-ring [55]. Also, it has been demonstrated that flavonols (quercetin and rutin) are more effective than flavanones (hesperetin and naringenin) in reducing MDA formation, which is associated with their ability to 
donate $\mathrm{H}$-atoms from $\mathrm{OH}$-groups. However, the flavanone naringenin exerted the highest interaction with phospholipidic bilayers [56].

Moreover, the quality of meat and meat products could be affected by Pox, which results in the loss of sulfhydryl groups and the carbonyl compounds formation [3]. Protein carbonyls can be generated by (1) direct oxidation of amino acid (lysine, arginine, and proline) side chains, (2) fragmentation of peptide backbone, (3) reactions with reducing sugars, and (4) binding non-protein carbonyl compounds [57]. In our study, Pox values increased during storage regardless of low temperatures. At the end of storage, the incorporation of antioxidants decreased Pox in beef patties $(47.3 \%, 21.9 \%$, and $19.4 \%$ for PEE, BHT, and Asc, respectively). In the same way, the incorporation of antioxidants reduced Pox in pork samples, with samples treated with PEE showing the higher reduction values, followed by Asc and BHT (30.6\%, $10 \%$, and $2.7 \%$, respectively). In agreement, black currant extract $(2 \%)$ and BHT $(0.2 \%)$ addition to pork patties decreased Pox during storage (9 days at $4{ }^{\circ} \mathrm{C}$ ) in a dose-dependent manner in comparison to the control [58]. In addition, it has been reported that the highest effectiveness of natural extracts against Pox (e.g., curry, cocoa, green tea, oregano, peanut, rosemary, olive, grape, avocado, and broccoli) are rich in phenolic compounds, which may be associated with the faster occurrence of Lox than Pox, and to the interaction between flavonoids and proteins [59-61]. In our study, a positive correlation $\left(r^{2}=0.83\right)$ was found between Lox and Pox, which demonstrated that both are a timely couple in meat samples [3].

The phenolic compounds identified in PEE (e.g., gallic acid and some flavonols) have been described as inhibitors of carbonyl compound formation from myofibrillar proteins [62]. Additionally, it has been reported that ferulic acid, malvidin, and rutin reduced, in vitro, the losses of tryptophan and lysine associated with Pox [63]. In this context, our results showed that the incorporation of PEE reduced Pox, which could be associated with the phenolic compound-protein interaction mechanisms and correlated to the hydrophobicity of the aromatic ring of polyphenols and to their OH-groups allowing the H-bonding $[13,57]$.

In meat and meat products, color influences the acceptability and plays a great role in the purchase decision, as consumers relate color with sensory attributes (flavor and tenderness) and another's parameters, such as nutritional value, satisfaction level and storage time [64]. In our study, the initial $\mathrm{L}^{*}$ and $\mathrm{a}^{*}$ values of beef and pork samples were not affected by PEE incorporation, except for $\mathrm{b}^{*}, \mathrm{C}$, and $h$ angle. At the end of storage, beef and pork patties with PEE showed lower $L^{*}(1.7$ and $3.0 \%$, respectively) and $\mathrm{h}^{*}$ values (22.1 and $13.4 \%$, respectively), as well as the higher $\mathrm{a}^{*}$ (38.7 and $26.1 \%$, respectively), $b^{*}$ (28 and $15.7 \%$, respectively), and $C^{*}$ values (33.8 and $21.7 \%$, respectively) than those obtained in control samples. In agreement, PEE increased the red color of beef patties during storage $19.4 \%$ (8 days at $\left.2{ }^{\circ} \mathrm{C}\right)$ in comparison to the control [29].

Furthermore, the discoloration observed in the surface of raw patties is associated with metmyoglobin formation $(\mathrm{MMb})$, which in fresh meat myoglobin $(\mathrm{Mb})$ is commonly found in three forms: oxymyoglobin [oxy $\left(\mathrm{Fe}^{2+}\right) \mathrm{Mb}$ ], deoxymyoglobin $\left[\operatorname{deoxy}\left(\mathrm{Fe}^{2+}\right) \mathrm{Mb}\right.$, and metmyoglobin, $\left.\left[\operatorname{met}\left(\mathrm{Fe}^{3+}\right) \mathrm{Mb}\right)\right][65]$. In our work, $\mathrm{MMb}$ values increased during storage time regardless of low temperatures; however, at the end of storage, the incorporation of antioxidants decreased $\mathrm{MMb}$ in the order PEE > BHT > Asc in beef $(49.3 \%, 33.4 \%$, and 39.4\%, respectively). A similar behavior was also found in porcine patties where the incorporation of antioxidants decreased $\mathrm{MMb}$, with the samples treated with PEE showing the largest decreases, followed by samples treated with Asc and BHT (58.1\%, $25.3 \%$, and $20.1 \%$, respectively) in comparison to the control.

The MMb values found for PEE during storage are below the limit values (above $40 \%$ ) that could be associated with decreases in sensory attributes of meat and meat products, and therefore, could affect the consumer purchase, rejecting the product [66]. In agreement, PEE reduced $58.6 \% \mathrm{MMb}$ in beef patties during storage ( 8 days at $2{ }^{\circ} \mathrm{C}$ ) compared to the control samples [29]. Other phenolic-rich extracts, such as tea extracts, seaweed, chestnut, grape seed, kimchi, lycopene, onion, oregano, pine bark, plum, red pepper, rice fiber, and rosemary, have also reported reduced color changes and $\mathrm{MMb}$ 
formation in meat samples during chilled storage [67-70]. Thus, our study results confirm the efficacy of PEE against Lox and Pox and color changes during chilled storage.

\section{Conclusions}

In this study, the current findings demonstrated an interesting phenolic composition of PEE, as well as high RPA and FRSA. Additionally, the addition of PEE (2\%) to raw beef and pork patties reduced Lox and Pox effectively, as well as the color changes that occur during the storage of meat $\left(2{ }^{\circ} \mathrm{C} /\right.$ under dark/for 10 days), in comparison with the synthetic antioxidants (BHT and Asc) and the control meat samples (without antioxidant). This study demonstrated great potential for PEE as a promising natural antioxidant for the food industry, increasing the shelf life of meat products, even in patties most susceptible to oxidation. However, further studies on the relationships between lipid and protein oxidation with sensorial quality in beef and porcine patties would need to be carried out in order to corroborate these promising outcomes since $\mathrm{MMb}$ percentages lower than $40 \%$ would be related to obtaining more attractive products for the consumers. Moreover, novel technologies, such as the active packaging and the microencapsulation, should be addressed to incorporate propolis extract on meat products, as well as a microbiological evaluation, which would allow the assessment of antimicrobial activity of this extract.

Author Contributions: R.D.V.-S., performed and designed the experiment; R.D.V.-S., G.R.T.-U., B.d.M.T.-M., M.P., J.M.L., and A.S.-E., analyzed the data, designed and revised the manuscript. All authors discussed the contents of the manuscript and approved the submission.

Acknowledgments: The authors also thank the technical assistance of Livier Zavala-Cárdenas. Rey D. Vargas-Sánchez gratefully acknowledges a fellowship from CONACYT for Ph.D. studies. Jose M. Lorenzo and Mirian Pateiro are members of the HealthyMeat network, funded by CYTED (ref. 119RT0568).

Conflicts of Interest: The authors declare no conflict of interest.

\section{References}

1. Pereira, P.M.D.C.C.; Vicente, A.F.D.R.B. Meat nutritional composition and nutritive role in the human diet. Meat Sci. 2013, 93, 586-592. [CrossRef] [PubMed]

2. Williams, P. Nutritional composition of red meat. Nutr. Diet. 2007, 64, S113-S119. [CrossRef]

3. Lund, M.N.; Heinonen, M.; Baron, C.P.; Estévez, M. Protein oxidation in muscle foods: A review. Mol. Nutr. Food Res. 2011, 55, 83-95. [CrossRef] [PubMed]

4. Domínguez, R.; Pateiro, M.; Gagaoua, M.; Barba, F.J.; Zhang, W.; Lorenzo, J.M. A comprehensive review on lipid oxidation in meat and meat products. Antioxidants 2019, 8, 429. [CrossRef] [PubMed]

5. Pașca, C.; Coroian, A.; Socaci, S. Risks and benefits of food additives-Review. UASVM Anim. Sci. Biotechnol. 2018, 75, 71-79. [CrossRef]

6. Villalobos-Delgado, L.H.; Mateo, J.; Caro, I.; Ramos, M.-Y.L.; Mendez, N.G.; Cansino, R.G.; Mondragón, E.G.G. Natural antioxidants in fesh and processed meat. In Sustainable Meat Production and Processing; Galanakis, C.M., Ed.; Academic Press: Cambridge, MA, USA, 2019; pp. 207-236.

7. Cunha, L.C.M.; Monteiro, M.L.G.; Lorenzo, J.M.; Munekata, P.E.S.; Muchenje, V.; de Carvalho, F.A.L.; Conte-Junior, C.A. Natural antioxidants in processing and storage stability of sheep and goat meat products. Food Res. Int. 2018, 111, 379-390. [CrossRef]

8. Nikmaram, N.; Budaraju, S.; Barba, F.J.; Lorenzo, J.M.; Cox, R.B.; Mallikarjunan, K.; Roohinejad, S. Application of plant extracts to improve the shelf-life, nutritional and health-related properties of ready-to-eat meat products. Meat Sci. 2018, 145, 245-255. [CrossRef]

9. Lorenzo, J.M.; Pateiro, M.; Domínguez, R.; Barba, F.J.; Putnik, P.; Kovačević, D.B.; Shpigelman, A.; Granato, D.; Franco, D. Berries extracts as natural antioxidants in meat products: A review. Food Res. Int. 2018, 106, 1095-1104. [CrossRef]

10. Pateiro, M.; Barba, F.J.F.J.; Domínguez, R.; Sant'Ana, A.S.A.S.; Khaneghah, A.M.; Gavahian, M.; Gómez, B.; Lorenzo, J.M.J.M. Essential oils as natural additives to prevent oxidation reactions in meat and meat products: A review. Food Res. Int. 2018, 113, 156-166. [CrossRef] 
11. Pateiro, M.; Lorenzo, J.M.M.; Amado, I.R.R.; Franco, D. Effect of addition of green tea, chestnut and grape extract on the shelf-life of pig liver pâté. Food Chem. 2014, 147, 386-394. [CrossRef]

12. Madane, P.; Das, A.K.; Pateiro, M.; Nanda, P.K.; Bandyopadhyay, S.; Jagtap, P.; Barba, F.J.; Shewalkar, A.; Maity, B.; Lorenzo, J.M. Drumstick (Moringa oleifera) flower as an antioxidant dietary fibre in chicken meat nuggets. Foods 2019, 8, 307. [CrossRef] [PubMed]

13. Fernandes, R.P.P.; Trindade, M.A.; Tonin, F.G.; Pugine, S.M.P.; Lima, C.G.; Lorenzo, J.M.; de Melo, M.P. Evaluation of oxidative stability of lamb burger with Origanum vulgare extract. Food Chem. 2017, 233, 101-109. [CrossRef] [PubMed]

14. Sánchez-Escalante, A.; Torrescano, G.; Djenane, D.; Beltrán, J.A.; Roncalés, P. Stabilisation of colour and odour of beef patties by using lycopene-rich tomato and peppers as a source of antioxidants. J. Sci. Food Agric. 2003, 83, 187-194. [CrossRef]

15. Farré, R.; Frasquet, I.; Sánchez, A. El própolis y la salud. Ars Pharm. J. 2004, 45, 23-43.

16. Cauich-Kumul, R.; Campos, M.R.S. Bioactive compounds. In Bee Propolis: Properties, Chemical Composition, Applications, and Potential Health Effects; Woodhead Publishing: Sawston/Cambridge, UK, 2019; pp. 227-243.

17. Sánchez, R.D.V.; Urrutia, G.R.T.; Escalante, A.S. El propóleos: Conservador potencial para la industria alimentaria. Interciencia 2013, 38, 705-711.

18. Pobiega, K.; Kraśniewska, K.; Gniewosz, M. Application of propolis in antimicrobial and antioxidative protection of food quality-A review. Trends Food Sci. Technol. 2019, 83, 53-62. [CrossRef]

19. Kunrath, C.A.; Savoldi, D.C.; Mileski, J.P.F.; Novello, C.R.; Alfaro, A.D.T.; Marchi, J.F.; Tonial, I.B. Application and evaluation of propolis, the natural antioxidant in Italian-type salami. Braz. J. Food Technol. 2017, 20, e2016035. [CrossRef]

20. Kročko, M.; Bobko, M.; Bučko, O.; Čanigová, M.; Ducková, V. Sensory quality, colour and oxidative stability of cured cooked ham with propolis extract. Potravinarstvo 2014, 8, 102-106. [CrossRef]

21. Vargas-Sánchez, R.D.; Torrescano-Urrutia, G.R.; Ramírez-Rojo, M.I.; Sánchez-Escalante, A. Propolis extract as an oxidative stabilizer of raw beef and pork patties during chilled storage. In Proceedings of the 61st International Congress of Meat Science and Technology, Clermont-Ferrand, France, 23-28 August 2015.

22. Shavisi, N.; Khanjari, A.; Basti, A.A.; Misaghi, A.; Shahbazi, Y. Effect of PLA films containing propolis ethanolic extract, cellulose nanoparticle and Ziziphora clinopodioides essential oil on chemical, microbial and sensory properties of minced beef. Meat Sci. 2017, 124, 95-104. [CrossRef]

23. Dos Reis, A.S.; Diedrich, C.; de Moura, C.; Pereira, D.; de Flório Almeida, J.; da Silva, L.D.; Plata-Oviedo, M.S.V.; Tavares, R.A.W.; Carpes, S.T. Physico-chemical characteristics of microencapsulated propolis co-product extract and its effect on storage stability of burger meat during storage at $-15^{\circ} \mathrm{C}$. LWT Food Sci. Technol. 2017, 76, 306-313. [CrossRef]

24. Bernardi, S.; Favaro-Trindade, C.S.; Trindade, M.A.; Balieiro, J.C.C.; Cavenaghi, A.D.; Contreras-Castillo, C.J. Italian-type salami with propolis as antioxidant. Ital. J. Food Sci. 2013, 25, 433-440.

25. Hernandez, J.; Goycoolea, F.; Quintero, J.; Acosta, A.; Castañeda, M.; Dominguez, Z.; Robles, R.; Vazquez-Moreno, L.; Velazquez, E.; Astiazaran, H.; et al. Sonoran propolis: Chemical composition and antiproliferative activity on cancer cell lines. Planta Med. 2007, 73, 1469-1474. [CrossRef]

26. Ainsworth, E.A.; Gillespie, K.M. Estimation of total phenolic content and other oxidation substrates in plant tissues using Folin-Ciocalteu reagent. Nat. Protoc. 2007, 2, 875-877. [CrossRef] [PubMed]

27. Oyaizu, M. Studies on products of browning reaction-antioxidative activities of products of browning reaction prepared from glucosamine. Jpn. J. Nutr. Diet. 1986, 44, 307-315. [CrossRef]

28. Molyneux, P. The use of stable free radical diphenylpicrylhydrazyl (DPPH) for estimating antioxidant activity. Songklanakarin J. Sci. Technol. 2004, 26, 211-219.

29. Vargas-Sánchez, R.D.; Torrescano-Urrutia, G.R.; Acedo-Félix, E.; Carvajal-Millán, E.; González-Córdova, A.F.; Vallejo-Galland, B.; Torres-Llanez, M.J.; Sánchez-Escalante, A. Antioxidant and antimicrobial activity of commercial propolis extract in beef patties. J. Food Sci. 2014, 79, C1499-C1504. [CrossRef]

30. Huang, B.; He, J.; Ban, X.; Zeng, H.; Yao, X.; Wang, Y. Antioxidant activity of bovine and porcine meat treated with extracts from edible lotus (Nelumbo nucifera) rhizome knot and leaf. Meat Sci. 2011, 87, 46-53. [CrossRef]

31. Association of Official Analytical Chemists (AOAC). Official Methods of Analysis; Association of Official Analytical Chemists: Gaitherburg, MD, USA, 2005.

32. Commision International de I’Eclairage (CIE). Recommendations of Uniform Color Spaces-Color Difference Equations Psychometric Color Terms; Commision International de I'Eclairage: Vienna, Austria, 1978. 
33. Stewart, M.R.; Zipser, M.W.; Watts, B.M. The use of reflectance spectrophotometry for the assay of raw meat pigments. J. Food Sci. 1965, 30, 464-469. [CrossRef]

34. Pfalzgraf, A.; Frigg, M.; Steinhart, H. Alpha-tocopherol contents and lipid oxidation in pork muscle and adipose tissue during storage. J. Agric. Food Chem. 1995, 43, 1339-1342. [CrossRef]

35. Oliver, C.N.; Ahn, B.W.; Moerman, E.J.; Goldstein, S.; Stadtman, E.R. Age-related changes in oxidized proteins. J. Biol. Chem. 1987, 62, 5488-5491.

36. Kocot, J.; Kiełczykowska, M.; Luchowska-Kocot, D.; Kurzepa, J.; Musik, I. Antioxidant potential of propolis, bee pollen, and royal jelly: Possible medical application. Oxid. Med. Cell. Longev. 2018, 2018, 7074209. [CrossRef] [PubMed]

37. Valencia, D.; Alday, E.; Robles-Zepeda, R.; Garibay-Escobar, A.; Galvez-Ruiz, J.C.; Salas-Reyes, M.; Jiménez-Estrada, M.; Velazquez-Contreras, E.; Hernandez, J.; Velazquez, C. Seasonal effect on chemical composition and biological activities of Sonoran propolis. Food Chem. 2012, 131, 645-651. [CrossRef]

38. Biskup, I.; Golonka, I.; Gamian, A.; Sroka, Z. Antioxidant activity of selected phenols estimated by ABTS and FRAP methods. Postepy Hig. Med. Dosw. 2013, 67, 958-963. [CrossRef] [PubMed]

39. Marković, Z.; Milenković, D.; Đorović, J.; Marković, J.M.D.; Stepanić, V.; Lučić, B.; Amić, D. PM6 and DFT study of free radical scavenging activity of morin. Food Chem. 2012, 134, 1754-1760. [CrossRef]

40. Geckil, H.; Ates, B.; Durmaz, G.; Erdogan, S.; Yilmaz, I. Antioxidant, free radical scavenging and metal chelating characteristics of propolis. Am. J. Biochem. Biotechnol. 2005, 1, 27-31. [CrossRef]

41. Lorenzo, J.M.J.M.; Vargas, F.C.; Strozzi, I.; Pateiro, M.; Furtado, M.M.; Sant'Ana, A.S.; Rocchetti, G.; Barba, F.J.; Dominguez, R.; Lucini, L.; et al. Influence of pitanga leaf extracts on lipid and protein oxidation of pork burger during shelf-life. Food Res. Int. 2018, 114, 47-54. [CrossRef]

42. Gheisari, H.R.; Motamedi, H. Chloride salt type/ionic strength and refrigeration effects on antioxidant enzymes and lipid oxidation in cattle, camel and chicken meat. Meat Sci. 2010, 86, 377-383. [CrossRef]

43. Serpen, A.; Gökmen, V.; Fogliano, V. Total antioxidant capacities of raw and cooked meats. Meat Sci. 2012, 90, 60-65. [CrossRef]

44. Mielnik, M.B.; Rzeszutek, A.; Triumf, E.C.; Egelandsdal, B. Antioxidant and other quality properties of reindeer muscle from two different Norwegian regions. Meat Sci. 2011, 89, 526-532. [CrossRef]

45. Fasseas, M.K.; Mountzouris, K.C.; Tarantilis, P.A.; Polissiou, M.; Zervas, G. Antioxidant activity in meat treated with oregano and sage essential oils. Food Chem. 2008, 106, 1188-1194. [CrossRef]

46. Hawashin, M.D.; Al-Juhaimi, F.; Ahmed, I.A.M.; Ghafoor, K.; Babiker, E.E. Physicochemical, microbiological and sensory evaluation of beef patties incorporated with destoned olive cake powder. Meat Sci. 2016, 122, 32-39. [CrossRef] [PubMed]

47. Torrescano, G.; Sánchez-Escalante, A.; Giménez, B.; Roncalés, P.; Beltrán, J.A. Shear values of raw samples of 14 bovine muscles and their relation to muscle collagen characteristics. Meat Sci. 2003, 64, 85-91. [CrossRef]

48. Kim, Y.H.B.; Warner, R.D.; Rosenvold, K. Influence of high pre-rigor temperature and fast $\mathrm{pH}$ fall on muscle proteins and meat quality: A review. Anim. Prod. Sci. 2014, 54, 375-395. [CrossRef]

49. Frankel, E.N. Lipid oxidation: Mechanisms, products and biological significance. J. Am. Oil Chem. Soc. 1984, 61, 1908-1917. [CrossRef]

50. Pereira, A.L.F.; Abreu, V.K.G. Lipid peroxidation in meat and meat products. In Lipid Peroxidation; Mansour, M.A., Ed.; IntechOpen: London, UK, 2018.

51. Raharjo, S.; Sofos, J.N. Methodology for measuring malonaldehyde as a product of lipid peroxidation in muscle tissues: A review. Meat Sci. 1993, 35, 145-169. [CrossRef]

52. Georgantelis, D.; Blekas, G.; Katikou, P.; Ambrosiadis, I.; Fletouris, D.J. Effect of rosemary extract, chitosan and $\alpha$-tocopherol on lipid oxidation and colour stability during frozen storage of beef burgers. Meat Sci. 2007, 75, 256-264. [CrossRef]

53. Zahid, M.A.; Seo, J.-K.; Parvin, R.; Ko, J.; Yang, H.-S. Comparison of butylated hydroxytoluene, ascorbic acid, and clove extract as antioxidants in fresh beef patties at refrigerated storage. Food Sci. Anim. Resour. 2019, 39, 768-779. [CrossRef]

54. Han, S.K.; Park, H.K. Accumulation of thiobarbituric acid-reactive substances in cured pork sausages treated with propolis extracts. J. Sci. Food Agric. 2002, 82, 1487-1489. [CrossRef]

55. Tsuchiya, H. Structure-dependent membrane interaction of flavonoids associated with their bioactivity. Food Chem. 2010, 120, 1089-1096. [CrossRef] 
56. Saija, A.; Scalese, M.; Lanza, M.; Marzullo, D.; Bonina, F.; Castelli, F. Flavonoids as antioxidant agents: Importance of their interaction with biomembranes. Free Radic. Biol. Med. 1995, 19, 481-486. [CrossRef]

57. Xiong, Y.L. Protein oxidation and implications for muscle foods quality. In Antioxidants in Muscle Foods; Decker, E.A., Faustman, C., Lopez-Bote, C.J., Eds.; Wiley: New York, NY, USA, 2000; pp. 85-111.

58. Jia, N.; Kong, B.; Liu, Q.; Diao, X.; Xia, X. Antioxidant activity of black currant (Ribes nigrum L.) extract and its inhibitory effect on lipid and protein oxidation of pork patties during chilled storage. Meat Sci. 2012, 91, 533-539. [CrossRef] [PubMed]

59. Falowo, A.B.; Fayemi, P.O.; Muchenje, V. Natural antioxidants against lipid-protein oxidative deterioration in meat and meat products: A review. Food Res. Int. 2014, 64, 171-181. [CrossRef] [PubMed]

60. Fernandes, R.P.P.; Trindade, M.A.; Lorenzo, J.M.; Munekata, P.E.S.; de Melo, M.P. Effects of oregano extract on oxidative, microbiological and sensory stability of sheep burgers packed in modified atmosphere. Food Control 2016, 63, 65-75. [CrossRef]

61. Lorenzo, J.M.; Munekata, P.E.S.; Sant'Ana, A.S.; Carvalho, R.B.; Barba, F.J.; Toldrá, F.; Mora, L.; Trindade, M.A. Main characteristics of peanut skin and its role for the preservation of meat products. Trends Food Sci. Technol. 2018, 77, 1-10. [CrossRef]

62. Estévez, M.; Heinonen, M. Effect of phenolic compounds on the formation of $\alpha$-aminoadipic and $\gamma$-glutamic semialdehydes from myofibrillar proteins oxidized by copper, iron, and myoglobin. J. Agric. Food Chem. 2010, 58, 4448-4455. [CrossRef]

63. Heinonen, M.; Rein, D.; Satué-Gracia, M.T.; Huang, S.-W.; German, J.B.; Frankel, E.N. Effect of protein on the antioxidant activity of phenolic compounds in a lecithin-liposome oxidation system. J. Agric. Food Chem. 1998, 46, 917-922. [CrossRef]

64. Girolami, A.; Napolitano, F.; Faraone, D.; Braghieri, A. Measurement of meat color using a computer vision system. Meat Sci. 2013, 93, 111-118. [CrossRef]

65. Faustman, C.; Sun, Q.; Mancini, R.; Suman, S.P. Myoglobin and lipid oxidation interactions: Mechanistic bases and control. Meat Sci. 2010, 86, 86-94. [CrossRef]

66. Greene, B.E.; Hsin, I.M.; Zipser, M.Y.W. Retardation of oxidative color changes in raw ground beef. J. Food Sci. 1971, 36, 940-942. [CrossRef]

67. Lorenzo, J.M.; Sineiro, J.; Amado, I.R.; Franco, D. Influence of natural extracts on the shelf life of modified atmosphere-packaged pork patties. Meat Sci. 2014, 96, 526-534. [CrossRef]

68. Zamuz, S.; López-Pedrouso, M.; Barba, F.J.; Lorenzo, J.M.; Domínguez, H.; Franco, D. Application of hull, bur and leaf chestnut extracts on the shelf-life of beef patties stored under MAP: Evaluation of their impact on physicochemical properties, lipid oxidation, antioxidant, and antimicrobial potential. Food Res. Int. 2018, 112, 263-273. [CrossRef] [PubMed]

69. Pateiro, M.; Vargas, F.C.F.C.; Chincha, A.A.I.A.; Sant'Ana, A.S.A.S.; Strozzi, I.; Rocchetti, G.; Barba, F.J.F.J.; Domínguez, R.; Lucini, L.; do Amaral Sobral, P.J.P.J.; et al. Guarana seed extracts as a useful strategy to extend the shelf life of pork patties: UHPLC-ESI/QTOF phenolic profile and impact on microbial inactivation, lipid and protein oxidation and antioxidant capacity. Food Res. Int. 2018, 114, 55-63. [CrossRef]

70. Pateiro, M.; Lorenzo, J.; Vázquez, J.; Franco, D. Oxidation stability of pig liver pâté with increasing levels of natural antioxidants (grape and tea). Antioxidants 2015, 4, 102-123. [CrossRef] [PubMed]

Sample Availability: Samples of the compounds are not available from the authors. 